\title{
Physical activity and normal body mass of women aged 45-55
}

\author{
Maria Nowak, ${ }^{1}$ Ewa Szczepanowska ${ }^{2}$ \\ ${ }^{1}$ Institute of Physical Culture, Estkowskiego 13, 66-400 Gorzów Wielkopolski, \\ Poland, E-mail: maria-nowak@wp.pl \\ ${ }^{2}$ Institute of Physical Culture, Szczecin University, Piastów 40b, 71-065 \\ Szczecin, Poland
}

\begin{abstract}
The aim of this paper was to determine the degree to which physical activity in women aged 45-55 was an independent influence on body mass, as expressed by BMI, and to what degree it occurred in interaction with their level of education, financial status, and self-evaluated physical efficiency and health status. The material consisted of 212 female inhabitants of three cities in Poland, participating in physical exercises for at least one year. Statistical analysis of the collected data was carried out by the $\chi^{2}$ test, the $H$ test, the Mann-Whitney $U$ test, and analysis of variance (ANOVA). A statistically significant relation between the level of physical activity and BMI values was observed. Women with a medium and high level of physical activity were most often of normal body mass, whereas women with low activity were characteristically overweight. Analysis of the data revealed that the normal body mass of women aged 45-55 was influenced by: the level of physical activity, level of education, and financial status of respondents. Physical activity was an independent factor influencing normal body mass of women, irrespective of social features (i.e., education and financial status).
\end{abstract}

KEY WORDS women's life style, physical efficiency, health status, BMI

Prz. Antropol.-Anthropol. Rev. (2003), vol. 66, pp. 77-86, Tables 5. ISBN 83-8696992-X, ISSN 0033-2003

\section{Introduction}

Regular physical activity adapted to individual needs of humans beneficially influences health and physical condition in adulthood and is also a natural means of age retardation. It prevents and helps fight against obesity, without too rapid muscle mass reduction and decrease in muscle strength caused by muscular atrophy; it impedes senile stiffness of joints and a diminishing movement range, and it prevents detrimental changes in the circulatory system, thus promoting the physical efficiency and fitness necessary to maintain the quality of life. A complementary depiction of healthcare effects of physical activity 
was introduced by DRABIK [1995, 1996, $1997 a, b]$. The author also attributes psychosocial changes to enhanced physical activity: increased self-confidence, improvement of mood, and improvement of a nutrition pattern and general quality of life.

Data obtained from studies conducted under the Framingham program [SZOSTAK et al. 2000] confirm that obesity is one of the basic risk determinants of hypertension, myocardial ischemia, cerebral stroke and myocardial infarction. Increased physical activity and a healthy way of life are crucial in the prophylaxis and therapy of metabolic diseases, particularly in obesity and atherosclerosis, and type II diabetes in adults [ZIEMLAŃSKI 1992]. Physical exercise also diminishes the potential for renewed fat development after efficacious slimming [SZOSTAK et al. 2000, SzOSTAK 2000b]. Cross-sectional study results show that intensive aerobic exercise programs promote an increase in HDL cholesterol concentration in women [SZOSTAK and CYBULSKA 1990] before and after menopause [DOWLING 2001]. It is pertinent to emphasize that the beneficial effects of physical exercise last only for one or two days and, thus, regular physical activity is required [BIAŁKOWSKA and PACHOCKI 1994].

The desire for a slim figure, as advertised in the mass media, drives many to immense physical efforts and going on a variety of diets, often followed without insight and forethought. It seems, however, that maintenance of normal body mass is not problematical for a healthy, young woman. Problems appear subsequently around the menopause and are connected with different ailments. Other typically climacteric symptoms include an increase in body mass, caused by retardation of metabolic processes [NACHTIGALL et al. 1997], and in the post-menopausal period, osteoporosis [PAK 1989]. Simultaneously, physical activity is recognized as a beneficial therapeutic and prophylactic means for reducing climacteric ailments [ARTAL and SHERMAn 1998]. Physical exercise decreases the probability of osteoporosis, coronary artery occlusion, psychological disorders, obesity and its associated diseases and, in addition, facilitates elevation of the mood [SHANGOLD 1989]. It also accelerates metabolism, which facilitates maintenance of optimal body mass [COPE 1996]. Women performing exercises generally also possess better health status [NACHTIGALL et al. 1997, PAK 1989].

The aim of this work was to determine the relationship between body mass, as expressed by BMI, and physical activity, as well as some social factors (i.e., level of education and financial status) and physical factors (i.e., physical efficiency and health status). Two questions were asked: (1) To what degree do the abovementioned factors correlate with each other, and (2) to what degree does physical activity influence body mass independently, and in association with the rest of the factors.

\section{Materials and methods}

The present study formed part of an examination of women's lifestyles, carried out since 1998 in some cities in western Poland. In this study, 212 women aged 45-55 were examined. They participated regularly in organized groups, supervised by an instructor, in physical exercises for at least one year, 
and all were city dwellers (from Szczecin, Poznań, or Wrocław). Sample selection reflected the aims of this work as an attempt to show the relation between long-duration physical activity in women and their maintenance of normal body mass.

The method involved a diagnostic poll by means of questionnaire, interview and observation. In determining the physical activity level, the questionnaire (tested before in pilot trials) included questions concerning time interval of participation in exercises (expressed in years), frequency of participation in exercises in a week, and time of duration of these exercises (expressed in minutes). The approximate length of physical activity was calculated by multiplying number of years by number of exercise weeks in one year (the number of 35 weeks was accepted after consulting with sport instructors) and time of exercise in minutes during one week. The obtained result was converted to hours and subjected to comparative analyses.

Physical activity expressed by the number of exercise hours became a basic criterion for differentiating respondents. On the basis of obtained results, the sample was divided into quartiles by the method of quartile deviation. Then, three groups of different levels of physical activity were selected on the following basis: low - from 23 to 98 hours (group 1), medium - from 99 to 490 hours (group 2) and high - from 491 to 2800 hours (group 3) (Table 1).

BMI values were calculated on the basis of declared information on current body mass and body height. In the literature one can find research results on the reliability of declared values of body height and body mass; they largely coincide with measured data, particularly in the case of educated and affluent persons [PALTA et al. 1982, STEWART 1982]. According to the most popular criteria [HOWLEY and FRANKS 1997], a normal BMI value for women should be 20.0 to $24.9 \mathrm{~kg} / \mathrm{m}^{2}$; values in the range 25.0 to $29.9 \mathrm{~kg} / \mathrm{m}^{2}$ indicate overweight, and equal to or higher than $30.0 \mathrm{~kg} / \mathrm{m}^{2}$ indicate obesity [SZOSTAK et al. 2000]. BMI values below $20.0 \mathrm{~kg} / \mathrm{m}^{2}$ indicate underweight. In this study, however, two categories of BMI were adopted (division due to sample sizes): BMI equal to or under $24.9 \mathrm{~kg} / \mathrm{m}^{2}$ (as the norm), and BMI equal to or over 25.0 $\mathrm{kg} / \mathrm{m}^{2}$ (as overweight).

Chi-square was used as the test of independence to verify research hypotheses. Evaluation of the general differentiation was done by the Kruskal-Wallis $H$ test, whereas the Mann-Whitney $U$ test was used to compare the pairs of variables. The levels of significance: ${ }^{*} p<0.05,{ }^{* *} p<0.01$, and $* * * p<0.001$ were adopted for the statistical calcula-

Table 1. Characteristics and differentiation of the physical activity level of women

\begin{tabular}{lccrrc}
\hline Group & Physical activity level [in hours] & $N$ & Mean & Median \\
\hline 1 & Low & $23-98$ & 51 & 53.2 & 52.5 \\
2 & Medium & $99-490$ & 108 & 229.2 & 210.0 \\
3 & High & $491-2800$ & 53 & 1334.0 & 910.0 \\
\hline Total & & 212 & 463.2 & 210.0 \\
\hline
\end{tabular}


tions. In determining the relationship between physical activity and social variables on the one hand, and body mass, on the other, the two-way analysis of variance (ANOVA) was applied. The statistical analysis was performed using the computer program Statistica PL 1997.

\section{Results}

On the basis of the obtained results, it is observed that women who belong to two different categories of BMI differ from each other in the level of physical activity, expressed by the number of exercise hours. The relation between body mass and the level of physical activity is presented in Table 2 . The general, differentiation between groups of activity measured by the $H$ test was 7.86 and was statistically significant at $p<0.001$. Significant differences in the BMI mean value occurred between groups of activity: 1-2 and 1-3 $(p<0.001)$. Women with medium and high levels of physical activity usually had normal body mass, whereas persons with low activity were characterized by overweight. The statistical significance of differences in BMI categories in groups of physical activity was addi- tionally confirmed by the $\chi^{2}$ test $\left(14.75^{* * *} ; d f=2\right)$.

Physical activity is not the only factor correlating with body mass. Physical activity was undertaken mainly by educated women of financially advantaged status. It could be supposed that these factors show a relationship with the BMI value. This was checked to determine whether any relationship existed between the level of education and financial status and the level of physical activity (Table 3 ) and normal body mass in women aged 45-55 (Table 4). It was observed that physical activity was mostly undertaken by persons with a post-secondary, secondary technical, vocational or university education level $(p<0.01)$. A high level of physical activity was observed mainly in women with university education $\left(\chi^{2}=17.22 * *\right.$; $d f=6)$. Women with high and medium level of physical activity were characterized by a very good or good financial situation. Persons with low physical activity more often had sufficient and good financial conditions $\left(\chi^{2}=9.73^{*}\right.$; $d f=4)$. There were more women with university-level education in the group with normal body mass $\left(\chi^{2}=8.80^{*}\right.$; $d f=3)$ than in the overweight group.

Table 2. Characteristics and categories of BMI in relation to physical activity level

\begin{tabular}{|c|c|c|c|c|c|c|c|c|}
\hline \multirow{3}{*}{ Physical activity level } & \multicolumn{8}{|c|}{ BMI } \\
\hline & \multirow[t]{2}{*}{ Mean } & \multirow[t]{2}{*}{ SD } & \multicolumn{2}{|c|}{ Total } & \multicolumn{2}{|c|}{$<25.0$} & \multicolumn{2}{|c|}{$\geq 25.0$} \\
\hline & & & $\mathrm{N}$ & $\%$ & $\mathrm{~N}$ & $\%$ & $\mathrm{~N}$ & $\%$ \\
\hline Total & 24.56 & 3.38 & 212 & 100 & 131 & 61.8 & 81 & 38.2 \\
\hline 1. Low & 25.98 & 3.67 & 51 & $(24.1)$ & 20 & $(15.3)$ & 31 & $(38.3)$ \\
\hline 2. Medium & 24.21 & 3.33 & 108 & $(50.9)$ & 73 & $(55.7)$ & 35 & $(43.2)$ \\
\hline 3. High & 23.20 & 2.81 & 53 & $(25.0)$ & 38 & $(29.0)$ & 15 & $(18.5)$ \\
\hline
\end{tabular}

$H=7.86^{* * *} ; U:(1-2) z=2.97^{* * *},(1-3) z=3.15^{* * *},(2-3) z=0.55 ; \chi^{2}=14.75^{* * *}$ 
Table 3. Education and financial status versus physical activity level

\begin{tabular}{|c|c|c|c|c|c|}
\hline \multirow{3}{*}{ Factor } & \multicolumn{5}{|c|}{ Physical activity level } \\
\hline & \multicolumn{2}{|c|}{ Total } & \multirow{2}{*}{$\begin{array}{c}\text { Low } \\
\%\end{array}$} & \multirow{2}{*}{$\frac{\text { Medium }}{\%}$} & \multirow{2}{*}{$\begin{array}{c}\text { High } \\
\%\end{array}$} \\
\hline & $\mathrm{N}$ & $\%$ & & & \\
\hline \multicolumn{6}{|l|}{ Education } \\
\hline below secondary & 11 & 5.2 & 5.9 & 7.4 & - \\
\hline secondary & 16 & 7.5 & 13.7 & 6.5 & 3.8 \\
\hline above secondary & 68 & 32.1 & 43.1 & 31.5 & 22.6 \\
\hline university-level & 117 & 55.2 & 37.3 & 54.6 & 73.6 \\
\hline \multicolumn{6}{|l|}{ Financial status } \\
\hline very good & 81 & 38.8 & 36.0 & 40.0 & 45.8 \\
\hline medium & 107 & 51.2 & 44.0 & 55.2 & 51.9 \\
\hline sufficient & 21 & 10.0 & 20.0 & 4.8 & 2.3 \\
\hline
\end{tabular}

For relations between education and physical activity levels $\chi^{2}=17.22 * *$

For relations between financial status and physical activity levels $\chi^{2}=9.73 *$

Table 4. Education and financial status versus BMI

\begin{tabular}{|c|c|c|c|c|c|c|}
\hline \multirow{3}{*}{ Factor } & \multicolumn{6}{|c|}{ BMI } \\
\hline & \multicolumn{2}{|c|}{$<25.0$} & \multicolumn{2}{|c|}{$\geq 25.0$} & \multicolumn{2}{|c|}{ Total } \\
\hline & $\mathrm{N}$ & $\%$ & $\mathrm{~N}$ & $\%$ & $\mathrm{~N}$ & $\%$ \\
\hline \multicolumn{7}{|l|}{ Education } \\
\hline below secondary & 4 & 3.1 & 7 & 8.6 & 11 & 5.2 \\
\hline secondary & 30 & 22.9 & 29 & 35.8 & 59 & 27.8 \\
\hline above secondary & 16 & 12.2 & 9 & 11.1 & 25 & 11.8 \\
\hline university-level & 81 & 61.8 & 36 & 44.5 & 117 & 55.2 \\
\hline \multicolumn{7}{|l|}{ Financial status } \\
\hline very good & 49 & 38.3 & 32 & 40.5 & 81 & 38.8 \\
\hline medium & 71 & 55.5 & 36 & 45.6 & 107 & 51.2 \\
\hline sufficient & 8 & 6.2 & 11 & 13.9 & 19 & 10.0 \\
\hline
\end{tabular}

For relations between education and BMI $\chi^{2}=8.80^{*}$

For relations between financial status and BMI $\chi^{2}=4.12$

Women with the normal BMI more often had a good financial status, whereas the overweight women similarly evaluated their financial status as good and very good.

Relations between self-evaluation of physical efficiency and health status and the level of physical activity are demonstrated in Table 5. Women with the highest level of physical activity attained the highest self-evaluation result of personal physical efficiency, whereas these with the lowest activity $\left(\chi^{2}=\right.$ $\left.33.74^{* * *} ; d f=6\right)$ attained the lowest. 
Women characterized by the medium level of activity manifested mostly medium and low self-evaluation of physical efficiency. Persons with the low and medium level of physical activity had some difficulties in self-evaluation. With reference to self-evaluated health status, one can observe that women with the highest and medium levels of physical activity also evaluated their health the highest, whereas women with the lowest activity $\left(\chi^{2}=19.91^{* *} ; \quad d f=6\right)$ evaluated it lower (as medium and sufficient). However, a statistically significant relationship between self-evaluation of physical efficiency and BMI values was not observed. This is also true of the self-evaluation of health status and BMI values.

In order to answer the question whether physical activity was a factor independently influencing body mass (BMI) or by interaction with social factors (education and financial status) and physical ones (physical efficiency and health status), the two-way analysis of variance was applied. Results of this analysis show that the BMI value is modified by the level of physical activity $[F(3,208)=5.20 ; p<0.002]$. The hypothesis about the relationship of the level of physical activity and BMI values was also confirmed by the $H$ test, $U$ test, and $\chi^{2}$ test. On the other hand, there is no such relationship between the level of education and BMI $[F(3,208)=$ $2.30 ; p<0.08]$. It was also shown that interaction between physical activity and the level of education did not influence BMI values significantly. Therefore, it can be assumed that BMI values are affected by physical activity alone, independently of education and interaction of these factors.

Results of the analysis of variance show that BMI values are related to financial status $[F(2,204)=2.16$; $p<0.012]$. The hypothesis about the relationship between financial status and BMI values was not confirmed by the $\chi^{2}$

Table 5. Self-evaluation of physical efficiency and health status versus physical activity level

\begin{tabular}{|c|c|c|c|c|c|c|c|c|}
\hline \multirow{3}{*}{ Self-evaluation } & \multicolumn{8}{|c|}{ Physical activity level } \\
\hline & \multicolumn{2}{|c|}{ Low } & \multicolumn{2}{|c|}{ Medium } & \multicolumn{2}{|c|}{ High } & \multicolumn{2}{|c|}{ Total } \\
\hline & $\mathrm{N}$ & $\%$ & $\mathrm{~N}$ & $\%$ & $\mathrm{~N}$ & $\%$ & $\mathrm{~N}$ & $\%$ \\
\hline \multicolumn{9}{|c|}{ Physical efficiency } \\
\hline high & 6 & 12.0 & 29 & 26.9 & 27 & 50.9 & 62 & 29.4 \\
\hline medium & 28 & 56.0 & 69 & 63.0 & 23 & 43.4 & 120 & 56.9 \\
\hline low & 12 & 24.0 & 6 & 5.5 & 3 & 5.7 & 21 & 9.9 \\
\hline cannot tell & 4 & 8.0 & 4 & 3.7 & - & - & 8 & 3.8 \\
\hline \multicolumn{9}{|l|}{ Health status } \\
\hline very good & 12 & 24.0 & 58 & 54.2 & 31 & 59.6 & 101 & 48.3 \\
\hline medium & 22 & 44.0 & 26 & 24.3 & 14 & 26.9 & 62 & 29.7 \\
\hline sufficient & 13 & 26.0 & 18 & 16.8 & 3 & 5.8 & 34 & 16.3 \\
\hline cannot tell & 3 & 6.0 & 5 & 4.7 & 4 & 7.7 & 12 & 5.7 \\
\hline
\end{tabular}

For relations between self-evaluation of physical efficiency and physical activity levels $\chi^{2}=33.74 * * *$

For relations between self-evaluation of health status and physical activity levels $\chi^{2}=19.91 * *$ 
test. It was also found that interaction between physical activity and financial status did not influence BMI values significantly. BMI values are influenced by the physical activity level and financial status of respondents.

It was also established that the BMI value was related to physical efficiency level $[F(3,207)=5.68 ; p<0.001]$ (the hypothesis about the relationship between physical activity and level of physical efficiency was confirmed by the result of the $\chi^{2}$ test $=33.74 * * *$; $d f=6$ ). It was further found that interaction between physical activity and physical efficiency did not influence BMI values significantly. BMI was also related to health status in the selfevaluation component $[F(5,203)=$ $1.43 ; p<0.022]$. It was also found that interaction between physical activity and health status did not influence BMI values significantly. It may be assumed that BMI values are affected by the physical activity level.

\section{Discussion}

The frequently cited work of BLAXTER [1995] takes into consideration four classical behaviors connected with health: diet, physical activity, smoking, and alcohol consumption. The above-mentioned behaviors are consistent with a pro-healthy way of life concept promoted by the WHO. Polish nation-wide statistical studies [KUCIARSKA-CIESIELSKA 1998] show that over $50 \%$ of adult Poles spend their leisure time in a passive way, which means that these people watch TV, read books or magazines. About $40 \%$ of women combine passive and low-activity rest, e.g., walking, and $15 \%$ of women combine passive rest with activities demanding higher activity, e.g., cycling, jogging, work in gardens, and practicing sport. In accordance with research results of the Bridging East-West Health Gap project [DRYGLAS et al. 2002], only 7\% of women in Poland declared high physical activity.

Many studies carried out in the USA, Australia, and many European countries have shown that a low level of physical activity is associated with risk factors (smoking, obesity, overweight) and is characteristic of persons of the lowest income and education levels [STEPTOE et al. 1997, POMERLAU et al. 1997]. These data have their justification in normal body mass research results. The Polish population has been shown to include $38 \%$ overweight women (BMI in the range of $25.0-30.0 \mathrm{~kg} / \mathrm{m}^{2}$ ), and $30 \%$ obese women $\left(\mathrm{BMI}>30.0 \mathrm{~kg} / \mathrm{m}^{2}\right)$ [BIAŁKOWSKA and PACHOCKI 1994]. Obesity is a phenomenon occurring commonly in economically developed countries [SEIDEL 1995]. The tendency for the percentage of obese persons to increase has also occurred in Poland, as was shown by a Pol-Monica study [SzOSTAK 2000a] among Warsaw inhabitants. In 1993, 35.9\% of women had normal body mass, $35.1 \%$ were overweight, and $29.0 \%$ were obese.

In the light of the results of the present study, women with a high level of physical activity had more frequently a normal body mass, while those with a low level of physical activity were more often overweight. The relationship between physical activity and obesity is a confirmation of the results of an international research carried out among over 15,000 adult inhabitants of the European Union [KEARNEY et al. 1999, GIBNEY 
1999, SzOSTAK et al. 2000]. Spending leisure time in a physically non-active way tended to increase BMI, whereas active forms of spending leisure time were favorable to maintaining normal body mass.

From the research carried out in 19831999 on overweight and obesity in a sample of 35,000 adult inhabitants of Wrocław, it was concluded that age, sex and social status influence the BMI values significantly. The increase in the percentage of overweight women is socially differentiated: between the 3rd and 6th life decades, fractions of overweight women increase among representatives of the intelligentsia from 16 to $60 \%$, among office workers from 18 to $72 \%$, and among women working physically from 27 to $83 \%$ [WELON and JANKOWSKA 2002]. Long-term observations show that BMI values rise regularly, particularly among middleaged persons and those with lower education levels [PIETINEN et al. 1996, WELON and JANKOWSKA 2002]. The results of the present study have confirmed the correlation of high physical activity and achieving normal body mass with a higher education level. High self-evaluation of health status and physical efficiency were also typical of women with high physical activity. This relationship was also observed when comparing women who were physically passive and active [TUROSZ and PACHOLCZAK 2001].

According to the Central Statistical Office studies on the health status of Polish people [KUCIARSKA-CIESIELSKA 1998], with health status deterioration the percentage of persons resting actively tends to decrease. Leisure time is spent in a passive way or requiring little physical activity by $55.8 \%$ of persons with a very good health status, and $82.8 \%$ with a poor health status. Sport is practiced by $2.6 \%$ of adults, $13.4 \%$ of whom have good and $0.3 \%$ poor health status. It is difficult to decide (on the basis of our own results) if physical activity is taken up by generally healthier persons or if the observed good health is a result of physical activity, since health status examinations were not carried out in the period when this activity started [KEMPER 2001]. Questionnaire studies can be used in accumulating information about the regularity of physical activity as a form of spending leisure time [LAMB and BRODIE 1990, SZEKLICKI 2000]. The validity and reliability of this method, also in determination of nutrition status of respondents, were confirmed by research results [PAWLĘGA et al. 1990, KRZYŻANOWSKA and UMŁAWSKA 2002].

\section{Final remarks}

The results of this study justify the conclusion that normal body mass of women aged 45-55 is influenced by the following factors: the physical activity level, education level, and financial status of respondents. A relationship with this variable is also shown by physical efficiency and health status (in self-evaluation). The level of education, financial status, self-evaluation of physical efficiency and health status are also correlated with physical activity of women. However, physical activity is a factor independently influencing normal body mass in women aged 45-55 irrespective of social features, such as education and financial status. 


\section{References}

ARTAL M., C. SHERMAN, 1998, Exercise against depression, Physician and Sportsmedicine, 26, 55-70

Bialkowska M., R. Pachocki, 1994, Wzmożona aktywność w leczeniu otyłości, [in:] Otyłość choroba cywilizacji, B. Baranowska, M. Białkowska, E. Wasilewska-Dziubińska, R. Pachocki (eds.), Bel Corp Sci. Publ., Warszawa

BlaXter M., 1995, Health and lifestyles, London, New York, Routledge

COPE J., 1996, Hormonalna terapia zastepcza $w$ praktyce lekarza rodzinnego, Wyd. Med. Sanmedia, Warszawa

Dowling E.A., 2001, How affects lipid profiles in women, Physician and Sportsmedicine, 29, 45-52

DRABIK J., 1995, Aktywność fizyczna w edukacji zdrowotnej spoleczeństwa, Cz. I. AWF, Gdańsk

DRABIK J., 1996, Aktywność fizyczna $w$ treningu zdrowotnym osób dorostych, Cz. II. AWF, Gdańsk

DRABIK J., 1997a, Promocja aktywności fizycznej (wprowadzenie do problematyki), Cz. III, AWF, Gdańsk

DRABIK J., 1997b, Aktywność, sprawność i wydolność fizyczna jako mierniki zdrowia człowieka, AWF, Gdańsk

Dryglas W., W. Bielecki, P. PUSKA, 2002, Ocena aktywności fizycznej mieszkańców sześciu krajów europejskich, Projekt „Bridging East-West Health Gap", Medycyna Sportowa, 18, 169-74

GiBNEY M.J., 1999, Nutrition, physical activity and health status in Europe: An overview, Public Health Nutrition, 2, 329-33

Howley E.T., B.D. FranKS, 1997, Health Fitness Instructors. Handbook, Champaign, Human Kinetics

KeARney J.M, C. DE GraAF, S. DAmKJaer, L.M. ENGSTROM, 1999, Stages of change towards physical activity in a nationally representative sample in the European Union, Public Health Nutrition, 2, 115-24

KEMPER H.C.G., 2001, The fitness and activity paradox: Are we fit because we are active? Or are we active because we are fit? Acta Kinesiologiae Universitatis Tartuensis, 6 (suppl.), 22-24

KRZYŻANOWSKA M., W. UMŁAWSKA, 2002, Zmierzona a deklarowana wysokość ciata, Wych. Fiz. Sport, 46, 181-88
KuCIARSKA-CIESIELSKA M., 1998, Statystyczne badania niektórych uwarunkowań zdrowia, Zdrowie Publiczne 5, 189-92

LAMB K.L., D.A. BRODIE, 1990, The assesment of physical activity by leisure - time physical activity questionnaires, Medicine and Science in Sports and Exercise, 10, 159-80

NAChtigall L., R.D. NAchtigall, J.R. HeIlman, 1997, Kobieta po czterdziestce. Obawy i nadzieje, PZWL, Warszawa

PAK C.Y.C.,1989, Pomenopauzalne zrzeszotnienie kości (osteoporoza), [in:] Menopauza, H.J. Buschbaum (ed.), PZWL, Warszawa, pp. 45-64

Palta M., R.J. Prineas, R. Berman, P. HANNAN, 1982, Comparison of self- reported and measured height and weight, Am. J. Epid., 115, 223-30

PaWlęga J., J. Rachtan, A. Sokolowski, 1990, Wiarygodność badań ankietowych na temat nałogów palenia tytoniu, picia alkoholu i sposobu odżywiania, Zdrowie Publiczne, 101, 457-64

Pietinen P., E. Vartiainen, S. Mannisto, 1996, Trends in body mass index and obesity among adults in Finland from 1972 to 1992, Int. J. Obes., 20, 114-20

Pomerlau J., L.L. Pederson, T. Ostbye, M. Speechley, K.N. Speechley, 1997, Health behaviours and socioeconomic status in Ontario, Canada, Europ. J. Epid., 13, 613-22

SHANGOLD M. M., 1989, Sport i gimnastyka, [in:] Menopauza, H.J. Buschbaum (ed.), PZWL, Warszawa, pp. 208-13

SEIDEL J.C.,1995, Obesity in Europe: Scaling an epidemic, Int. J. Obes., 19 (suppl. 3), 1-4

Steptoe A., J. Wardle, R. Fuller, A. Holte, J. Justo, R. SANDERMAN, L.WICHSTROM, 1997, Leisure - time physical exercise: Prevalence, attitudinal correlates, and behavioral correlates among young Europeans from 21 countries, Preventive Medicine, 26, 845-54

STEWART A.W.L, 1982, The reliability and validity of self-reported weight and height, Chronic Diseases in Canada, 35, 295-309

SzEKLICKI R., 2000, Metody pomiaru aktywności fizycznej, Wych. Fiz. Sport, 3, 3-20

SzostaK W.B., 2000a, Otyłość - problem o rosnacym znaczeniu na przełomie wieków, Medycyna po Dyplomie, Wyd. spec., marzec/kwiecień, pp. 7-11 
SzOSTAK W.B., 2000b, Zaburzenia metaboliczne w nadwadze $i$ otylości, Medycyna po Dyplomie, Wyd. spec., marzec/kwiecień, pp. 12-16

Szostak W.B., M. BialKowsKa, B. Cybulska, L. KŁosiewiCZ-LatosZEK, 2000, Leczenie otyłości u ludzi dorostych, Medycyna po Dyplomie, Wyd. spec., grudzień, pp. 163-80

Szostak W.B., B. Cybulska, (ed.), 1990, Metaboliczne choroby cywilizacyjne, Wyd. III, Centrum Medyczne Kształcenia Podyplomowego, Warszawa
TuROSZ M.A., J. PACHOLCZAK, 2001, Znaczenie aktywności ruchowej w ksztaltowaniu wysokiej samooceny $i$ postawy prozdrowotnej kobiet, Medycyna Sportowa, 17, 391-95

WELON Z., E.A. JANKOWSKA, 2002, Nadwaga i otylość w populacji wielkomiejskiej w Polsce w latach 1983-1999, Polski Merkuriusz Lekarski, 12(70), 295-98

ZIEMLAŃSKI Ś.,1992, Czlowiek $i$ środowisko a zdrowie, Wych. Fiz. i Zdrowotne, 2, 53-58

\section{Streszczenie}

Celem pracy było określenie zależności między masą ciała, wyrażoną wskaźnikiem BMI, a aktywnością fizyczną oraz cechami społecznymi (poziom wykształcenia i sytuacja materialna) i fizycznymi (sprawność fizyczna i stan zdrowia w samoocenie). Systematyczna aktywność fizyczna pozwala utrzymać prawidłową masę ciała, natomiast uczestnictwo w ćwiczeniach uwarunkowane jest wieloma czynnikami, m.in. społecznymi [STEPTOE et al. 1997, POMERLAU et al. 1997]. Postawiono więc pytanie, na ile aktywność fizyczna jest czynnikiem samodzielnie wpływającym na masę ciała kobiet w wieku 45-55 lat, wyrażoną wskaźnikiem $\mathrm{BMI}$, a na ile działa ona $\mathrm{w}$ interakcji $\mathrm{z}$ poziomem wykształcenia, sytuacją materialną $\mathrm{i}$, wynikającą z samooceny, sprawnością fizyczną i stanem zdrowia. Materiał badawczy stanowiło 212 mieszkanek dużych miast (Szczecin, Poznań, Wrocław), uprawiających ćwiczenia fizyczne co najmniej rok. W badaniach wykorzystano metodę sondażu diagnostycznego, z zastosowaniem techniki ankiety, wywiadu i obserwacji. Analizy statystycznej zebranego materiału dokonano przy pomocy testu $\chi^{2}$, testu $H$, testu $U$ - Manna-Whitney'a oraz dwuczynnikowej analizy wariancji (ANOVA). Wyłoniono trzy grupy kobiet o zróżnicowanym poziomie aktywności fizycznej (Tab. 1): niskim (grupa 1), średnim (grupa 2) i wysokim (grupa 3).

Pomiędzy poziomem aktywności fizycznej a kategoriami wskaźnika BMI zaobserwowano istotne statystycznie zróżnicowanie (Tab. 2). Kobiety o średnim i wysokim poziomie aktywności fizycznej najczęściej posiadały prawidłową masę ciała, natomiast kobiety o niskiej aktywności charakteryzowała częściej nadwaga. Stwierdzono, iż aktywność fizyczną najczęściej podejmowały osoby z wykształceniem średnim i wyższym, o bardzo dobrej i dobrej sytuacji materialnej (Tab. 3). Analogiczne obserwacje poczyniono w przypadku związków wykształcenia i sytuacji materialnej z wartościami wskaźnika BMI (Tab. 4). Najwyższą samoocenę zdrowia i osobistej sprawności fizycznej posiadały kobiety o najwyższym poziomie aktywności fizycznej, niższą - kobiety o najniższej aktywności (Tab. 5).

W wyniku przeprowadzonej analizy wariancji stwierdzono, że na masę ciała kobiet w wieku 45-55 lat wpływają następujące czynniki: poziom aktywności fizycznej, poziom wykształcenia, sytuacja materialna respondentek, sprawność fizyczna i stan zdrowia wyrażone samooceną. Wymienione czynniki (poziom wykształcenia, sytuacja materialna, samoocena sprawności fizycznej i zdrowia) warunkują również aktywność fizyczną kobiet (Tab. 3, 5). Jednakże aktywność fizyczna jest czynnikiem niezależnie od innych wpływającym na prawidłową masę ciała kobiet w wieku 45-55 lat $(F(3,208)=5.20 ; p<0.002)$; nie wykazuje interakcji z cechami społecznymi (wykształceniem i sytuacją materialna), ani samooceną cech fizycznych (sprawnością fizyczną i stanem zdrowia). 